\title{
ANTIOXIDANT ACTIVITY OF EIGHT TOMATO (LYCOPERSICON ESCULENTUML.) VARIETIES GROWN IN ALGERIA
}

\author{
Bachir Bey Mostapha ${ }^{1}$--- Louaileche Hayette ${ }^{2}$--- Mouhoubi Zina ${ }^{3}$ \\ ${ }_{1,2, s}$ Laboratoire de Biochimie Appliquée, Faculté des sciences de la nature et de la vie, Université de Bejaia, Bejaia, Algérie
}

\begin{abstract}
The harmful effects of the free radicals on human organism could be inhibited by antioxidants of fruits and vegetables such as tomato. In the present work, the antioxidant contents as well as the antioxidant activity of eight tomato varieties grown in Algeria are evaluated. Ascorbic acid and carotenoid contents are assessed using spectrophotometric methods. The phenolic compounds extracted using solvents with different polarities (methanol, 50\% methanol, ethanol, and 50\% ethanol) have been determined using the Folin-Ciocalteu reagent. The antioxidant activities have been evaluated using the DPPH scavenging activity and the reducing power assays. Ascorbic acid content ranged between 7 and $16.7 \mathrm{mg} / 100 \mathrm{~g}$ while carotenoid concentration varied from 5.7 to $9.57 \mathrm{mg} / 100 \mathrm{~g}$. The phenolic content varies according to the variety and the extraction solvent; pure alcohols (ethanol and methanol) allow better extraction than the diluted ones (50\% ethanol and 50\% methanol). Linear correlations are noted between the antioxidant activity and phenolic, carotenoid and lycopene contents. The results indicate that the samples present variations in their antioxidant substance amounts and antioxidant activity; this could be attributed to the varietal factor. The hybridisation between Joker and Marmande varieties, which present the highest phenolic and carotenoid amounts, respectively, could give another variety with a high antioxidant activity.
\end{abstract}

Keywords: Antioxidants, Tomato, Variety, Ascorbic acid, Carotenoids, Phenolics, Extraction solvent.

\section{Contribution/ Originality}

This study documents for the first time the phytochemical content (ascorbic acid, total carotenoids, lycopene and total phenolics) and antioxidant activity (DPPH radical scavenging activity and reducing power) of some tomato varieties grown in Algeria.

\section{INTRODUCTION}

Food can largely influence free radical effects on the organism. Thus, for a few years, the evidence has accumulated to affirm that an increase in the fruits and vegetables consumption is a good mean of protection against the free radicals. The preventive effects of these plants are due to the presence of some molecules such as polyphenolic compounds, carotenoids and certain vitamins 
which are opposed to the harmful action of these reactive substances (Wootton-Beard and Ryan, 2011; Harasym and Oledzki, 2014).

The epidemiological studies revealed a weak incidence of several diseases in the Mediterranean populations. This protection is due to the Mediterranean diet, which consists of vegetables and fruits intake generally, and tomato with the olive oil particularly (Weisburger, 2002; Grosso et al., 2013).

Tomato (Lycopersicon esculentum) is one of the most consumed foods throughout the world. 162 million tonnes are produced in the world and 0.8 million tonnes in Algeria in the year 2012 (FAO, 2012). Tomato is consumed raw, in salads, or after cooking. It is also used in the various derivative products (juice, paste,...). Dietary intake of tomato and tomato products containing lycopene has been shown to be associated with a decreased risk of chronic diseases such as cancer (breast, colon, prostate) and cardiovascular diseases (Agarwal and Rao, 2000; Willis and Wians, 2003).

Lycopene, the carotenoid which gives tomato its reddish colour, is one of the most powerful scavenger of oxygen singlet and free radicals in body, and plays an important role in many biological functions, such as the modulation of intercellular gap-junction communication, hormonal and immune systems, and metabolic pathways (Woodall et al., 1997; Livny et al., 2002; Blum et al., 2005; Basuny et al., 2009).

In addition to carotenoids, tomato contains a variety of natural antioxidants, including ascorbic acid and phenolic compounds. The antioxidant content of tomato mostly depends on both genetic and environmental factors and the ripening stage (Hart and Scott, 1995; George et al., 2004; Hallmann, 2012; Nour et al., 2013). To our knowledge, no information is available about antioxidant activity of Algerian tomato varieties. Therefore, the aim of this investigation is to determine the content of various antioxidant substances (ascorbic acid, total carotenoids, lycopene and total phenolics) and antioxidant activity of eight tomato varieties grown in Algeria.

\section{MATERIALSANDMETHODS}

\subsection{Tomato Samples}

Eight commercial tomato (Lycopercicon esculentum) varieties are used in this study. At the exception of Joker which was cultivated in open-air, all the other varieties (Marmande, Sammichele, Agora, Zahra, Tafna, Nattih and Kiti) were grown in greenhouse. The healthy fruits, freshly harvested, uniformly ripened at the red ripe stage, are analysed. $1 \mathrm{~kg}$ of each variety is selected randomly from three Algerian localities (Bejaia, Biskra and Tipaza), to study the different antioxidant contents and to explore the antiradical activity and the reducing power. Tomato fruits are crushed in a mortar and the homogeneous mass is taken for analysis.

\subsection{Ascorbic Acid Determination}

Ascorbic acid (AA) is determined according to the method of Klein and Perry (1982) with slight modifications. One gram of tomato homogenate is extracted with $10 \mathrm{ml}$ of $1 \%$ oxalic acid for $45 \mathrm{~min}$ and filtered. The filtrate $(3 \mathrm{ml})$ is mixed with $1 \mathrm{ml}$ of 2,6-dichloroindophenol and the 
absorbance is read at $515 \mathrm{~nm}$ using an UV-visible spectrophotometer (UVmini 1240, Schimadzu, China). The AA content, expressed as $\mathrm{mg} / 100 \mathrm{~g}$ fresh matter, is calculated on the basis of the Lascorbic acid calibration curve.

\subsection{Total Carotenoid and Lycopene Determination}

Carotenoids are extracted according to the method described by (Sadler et al., 1990); $2 \mathrm{~g}$ of sample are extracted with $20 \mathrm{ml}$ of $n$-hexane: acetone: ethanol (2:1:1) by shaking for 30min. The upper layer is pipetted into a $50 \mathrm{ml}$ flask and the extraction procedure is repeated for the bottom layer with $10 \mathrm{ml}$ of hexane. The absorbance of the combined extracts is measured at 420nm. Total carotenoid content is calculated according to the calibration curve of $\beta$-carotene, and expressed as milligrams per $100 \mathrm{~g}$ of fresh matter. The lycopene content is measured in the hexanic extract at $472 \mathrm{~nm}$ using an extinction coefficient $\mathrm{E}^{1 \%}{ }_{1 \mathrm{~cm}}$ of 3450 , as reported by Martínez-Valverde et al. (2002).

\subsection{Total Phenolics Determination}

Extraction is performed twice using the modified procedure of Mau et al. (2005). Four solvents, methanol, $50 \%$ methanol $(\mathrm{v} / \mathrm{v})$, ethanol and $50 \%$ ethanol $(\mathrm{v} / \mathrm{v})$ are used for the extraction of phenolic compounds. Five grams of homogenized tomatoes are extracted with $25 \mathrm{ml}$ of solvent for $24 \mathrm{~h}$ and the mixture is filtered. The residue is then extracted with additional $25 \mathrm{ml}$ of solvent as described above. The phenolic compound content in the combined extracts is determined according to Singleton and Rossi (1965) and the results are expressed as gallic acid equivalents (GAE) per $100 \mathrm{~g}$ fresh matter.

\subsection{DPPH Radical Scavenging Assay}

\subsubsection{DPPH Radical Scavenging Assay of Alcoholic Extracts}

The scavenging activity of alcoholic extracts for the radical 2,2-diphenyl-1-picryl-hydrazyl (DPPH) was determined after Brand-Williams et al. (1995); $1 \mathrm{ml}$ of the extract is added to $2 \mathrm{ml}$ of methanolic DPPH solution $(20 \mu \mathrm{g} / \mathrm{ml})$. The decolourizing process is recorded at $517 \mathrm{~nm}$, after 30 min of reaction and compared to a blank control. The percentage of $\mathrm{DPPH}^{*}$ scavenging is calculated according to the equation:

$\% \mathrm{DPPH}^{\cdot}{ }_{\text {scavenging }}=100\left(\mathrm{~A}_{\mathrm{c}}-\mathrm{A}_{\mathrm{s}}\right) / \mathrm{A}_{\mathrm{c}}$

$\mathrm{A}_{\mathrm{c}}=$ absorbance of control, $\mathrm{A}_{\mathrm{s}}=$ absorbance of sample.

\subsubsection{DPPH Radical Scavenging Assay of Hexanic Extracts}

The antioxidant activity of carotenoids is measured in terms of radical-scavenging ability according to the modified procedure of Jiménez-Escrig et al. (2000); 400 $\mu$ l of hexanic extract are mixed with $2 \mathrm{ml}$ of DPPH solution. The absorbance is measured at $580 \mathrm{~nm}$ and the percentage of $\mathrm{DPPH}^{*}$ scavenging is expressed as described above. 


\subsection{Reducing Power Determination}

The reducing power of the alcoholic extracts is determined by the method described by Yen and Chen (1995); $1 \mathrm{ml}$ of extracts is mixed with $2.5 \mathrm{ml}$ of phosphate buffer (0.2M, pH 6.6) and $2.5 \mathrm{ml}$ potassium ferricyanide $(1 \%)$. The mixture is incubated at $50^{\circ} \mathrm{C}$ for $20 \mathrm{~min} ; 2.5 \mathrm{ml}$ of trichloroacetic acid $(10 \%)$ is added to the mixture, which is then centrifuged at $1400 \mathrm{~g}$ (Sigma 2$16 \mathrm{~K}$ ) for $10 \mathrm{~min}$. Finally, $2.5 \mathrm{ml}$ of upper layer solution is mixed with $2.5 \mathrm{ml}$ distilled water and $0.5 \mathrm{ml} \mathrm{FeCl}{ }_{3}(0.1 \%)$; the absorbance is measured at $700 \mathrm{~nm}$.

\subsection{Statistical Analysis}

Experiments were performed in triplicate and results were expressed as means \pm standard error. Analysis of variance (ANOVA) is used and the least significant difference (LSD) at $\mathrm{p}<0.05$ is calculated using the Statistica 5.5 to determine significant differences between the results.

\section{RESULTS AND DISCUSSION}

\subsection{Ascorbic Acid Content}

The ascorbic acid contents of the analysed tomato samples varied from 6.94 (Agora) to $16.70 \mathrm{mg} / 100 \mathrm{~g}$ (Nattih) (Table 1). The ascorbic acid contents of the varieties present significant differences ( $<<0.05$ ), except Marmande and Tafna. These results are similar to those of Toor et al. (2006) on New Zealand tomatoes. However, the investigation of Abushita et al. (1997) shows that the concentration of this antioxidant ranged between 22 and $48 \mathrm{mg} / 100 \mathrm{~g}$ on tomato varieties cultivated in Hungary. George et al. (2004) reported that ascorbic acid concentration of 12 tomato varieties ranged between 8.4 and $32.4 \mathrm{mg} / 100 \mathrm{~g}$; Nour et al. (2013) reported similar contents (9.9$34 \mathrm{mg} / 100 \mathrm{~g}$ ) in tomato cultivars grown in southwestern Romania.

The greenhouse grown tomatoes are found to have lower levels of ascorbic acid than those grown outdoors because of the lower light intensity in the greenhouses (Dumas et al., 2003). This could explain the relative lower contents of ascorbic acid in the studied tomato varieties.

\subsection{Total Carotenoid and Lycopene Contents}

The highest carotenoid concentration is recorded for Marmande and Tafna varieties, followed by Kiti and Zahra. Carotenoid contents in Sammichele, Joker and Agora varieties do not present significant differences (Table 1). The carotenoid levels of the analysed tomato samples are higher than those reported by Abushita et al. (1997) (1.85-6mg/100g) and Zoran et al. (2014) (2.5$3.5 \mathrm{mg} / 100 \mathrm{~g})$. A large variation in the carotenoid content of the varieties could mainly be attributed to factors such as environment and genotype (George et al., 2004).

Lycopene concentrations in tomato varieties vary from 3.90 (Nattih) to $7.70 \mathrm{mg} / 100 \mathrm{~g}$ (Marmande) (Table 1). Lycopene contents of the eight analysed varieties are significantly different $(\mathrm{p}<0.05)$. The study performed by Martínez-Valverde et al. (2002) on Spanish varieties shows variations of the lycopene concentrations from 1.8 to $6.5 \mathrm{mg} / 100 \mathrm{~g}$. Contents from 0.5 to $6.3 \mathrm{mg} / 100 \mathrm{~g}$ are obtained by Kuti and Konuru (2005). The results found in this investigation were relatively higher than those reported by Nour et al. (2013) for tomato cultivars grown in 
southwestern Romania $(1.2-4.9 \mathrm{mg} / 100 \mathrm{~g})$ but lower than those obtained by Frusciante et al. (2007) and Pinela et al. (2012) for tomato varieties cultivated in Italy $(2.33-16.9 \mathrm{mg} / 100 \mathrm{~g})$ and Portuguese farmer varieties cultivated in homegardens (10.9-18.6mg/100g), respectively.

The lycopene constitutes 60 to $74 \%$ of the carotenoids of tomato and tomato products (Clinton, 1998). Shi and Le Maguer (2000) reported that lycopene represents 80 to $90 \%$ of total carotenoids. The lycopene content in the analysed samples varies from 64.09 to $80.48 \%$ (Table 1 ). These results confirm the existence of a good linear correlation between lycopene and total carotenoid contents $(\mathrm{r}=0.94)$.

Table-1. Ascorbic acid, carotenoid and lycopene contents of tomato varieties

\begin{tabular}{l|c|c|c|c}
\hline \multirow{2}{*}{ Variety } & \multirow{2}{*}{$\begin{array}{c}\text { Ascorbic acid } \\
(\mathbf{m g / 1 0 0 g})\end{array}$} & $\begin{array}{c}\text { Carotenoids } \\
\text { (mg/100g) }\end{array}$ & \multicolumn{2}{|c}{ Lycopene } \\
\cline { 4 - 5 } & $(\mathbf{m g} / \mathbf{1 0 0 g})$ & $7.70 \pm 0.01^{\mathrm{a}}$ & $80.48^{\mathrm{a}}$ \\
Marmande & $12.64 \pm 0.19^{\mathrm{e}}$ & $9.57 \pm 0.15^{\mathrm{a}}$ & $5.23 \pm 0.08^{\mathrm{f}}$ & $68.74^{\mathrm{e}}$ \\
Sammichele & $9.86 \pm 0.12^{\mathrm{f}}$ & $7.61 \pm 0.20^{\mathrm{d}}$ & $73.39^{\mathrm{d}}$ \\
Agora & $6.94 \pm 0.16^{\mathrm{g}}$ & $7.32 \pm 0.14^{\mathrm{d}}$ & $5.37 \pm 0,04^{\mathrm{e}}$ & $77.54^{\mathrm{bc}}$ \\
Zahra & $15.04 \pm 0.13^{\mathrm{c}}$ & $8.16 \pm 0.15^{\mathrm{c}}$ & $6.33 \pm 0.07^{\mathrm{d}}$ & $73.70^{\mathrm{d}}$ \\
Tafna & $12.60 \pm 0.07^{\mathrm{e}}$ & $9.46 \pm 0.10^{\mathrm{a}}$ & $6.98 \pm 0.04^{\mathrm{b}}$ & $75.46^{\mathrm{cd}}$ \\
Nattih & $16.70 \pm 0.21^{\mathrm{a}}$ & $5.18 \pm 0.23^{\mathrm{e}}$ & $3.90 \pm 0.03^{\mathrm{h}}$ & $79.28^{\mathrm{ab}}$ \\
Kiti & $14,55 \pm 0.02^{\mathrm{d}}$ & $8.56 \pm 0.25^{\mathrm{b}}$ & $6.78 \pm 0,02^{\mathrm{c}}$ & $64.09^{\mathrm{f}}$ \\
Joker & $15,43 \pm 0,26^{\mathrm{b}}$ & $7.35 \pm 0.11^{\mathrm{d}}$ & $4.71 \pm 0,03^{\mathrm{g}}$ & \\
\hline
\end{tabular}

Different letters in the same column indicate significant differences ( $<0.05)$

\subsection{Total Phenolic Contents}

The extraction of phenolics from plant tissue poses several problems, including the presence of different enzymes (e.g. polyphenol oxidases) that can oxidize the phenolics. Drying is a good method to remove the enzymatic activity, but it could cause decrease of the polyphenol contents (Ribéreau-Gayon, 1968). For this reason, fresh tomatoes were used. As polyphenols have variable polarities, different solvents were used in this study (methanol, 50\% methanol, ethanol and 50\% ethanol). Several authors have used water for extraction (Odabasoglu et al., 2004). However, water could dissolve undesired molecules such as proteins and polysaccharides, especially if the extraction is carried out at high temperatures (Shi et al., 2003). Mixtures alcohol/water are widely used for phenolic extractions (Chu et al., 2000; Martínez-Valverde et al., 2002).

The phenolic compound concentrations of tomato varieties are presented in Fig. 1. The phenolic contents in methanolic extracts (pure methanol) of the samples varied from 20.64mg/100g (Marmande) to 49.55mg/100g (Joker). The Sammichele, Agora, Zahra and Tafna varieties contain closer concentrations, approximately $24 \mathrm{mg} / 100 \mathrm{~g}$. The extraction by $50 \%$ methanol resulted in contents ranging between 17.96 and $37.80 \mathrm{mg} / 100 \mathrm{~g}$. The quantities of phenolic compounds extracted by this solvent are significantly different, except Agora and Sammichele.

As indicated in Fig. 1, the extraction with absolute ethanol gives a contents in phenolic compounds ranging between 22.53 (Marmande) and 51.58mg/100g (Joker). Agora and Zahra have similar phenolic levels; however, phenolic contents of the other varieties are significantly 
different $(\mathrm{p}<0.05)$. The concentrations from 20 to $30.25 \mathrm{mg} / 100 \mathrm{~g}$ were found for $50 \%$ ethanol extracts. Joker and Nattih varieties have similar contents; the values of Marmande and Zahra are also similar.

The solvents used in our investigation allow the extraction of phenolic compounds with significant differences $(\mathrm{p}<0.05)$. The best solvent of extraction is ethanol then methanol followed by $50 \%$ methanol and finally $50 \%$ ethanol.

Fig-1. Total phenolic contents of the tomato varieties

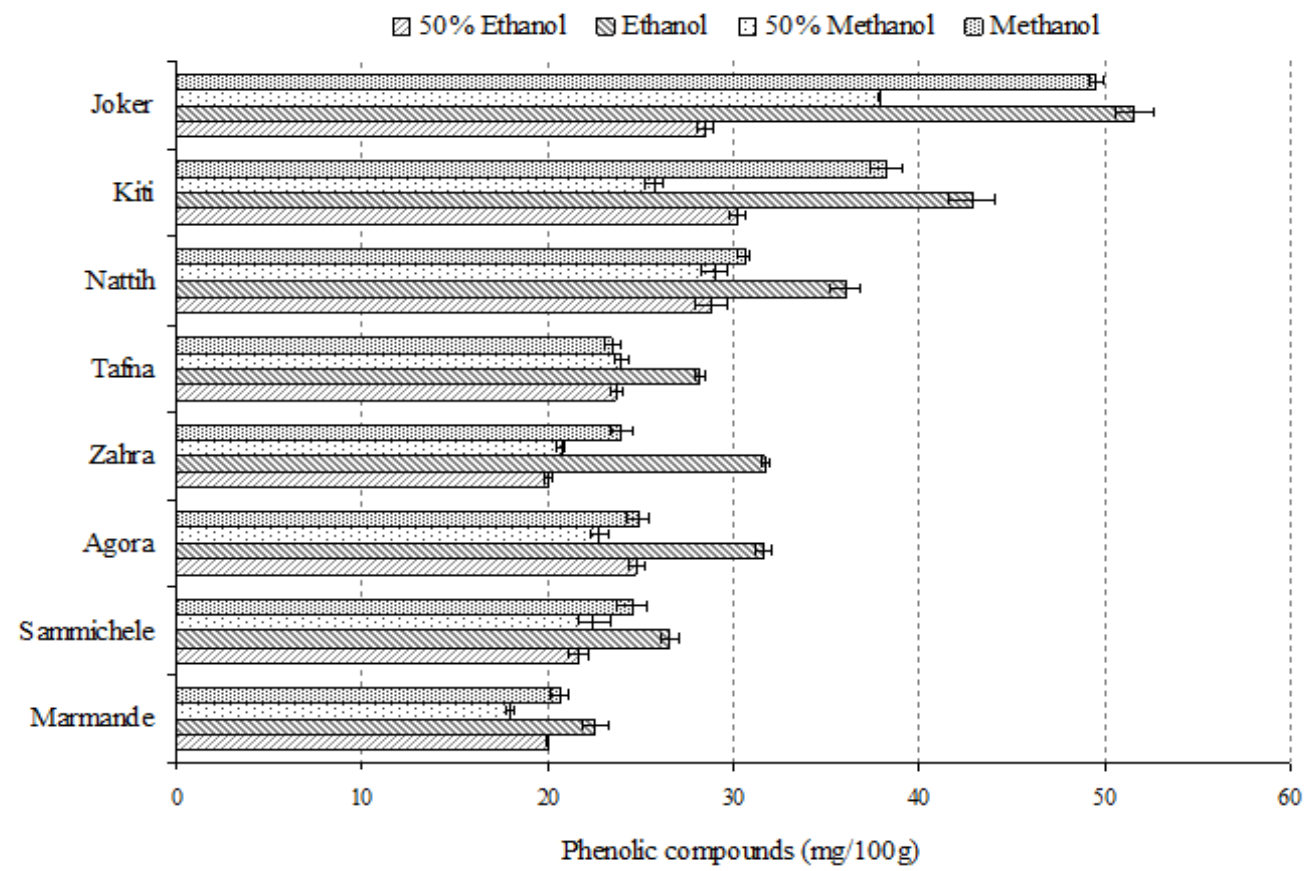

Bars represent the standard error of the mean.

The phenolic contents in the tomato varieties of this work are comparable with several findings of other studies. Similar concentrations are reported by Martínez-Valverde et al. (2002) in Spanish tomato. The phenolic content reported by Kaur and Kapoor (2002) in Indian tomato is $68 \mathrm{mg} / 100 \mathrm{~g}$. The Italian tomato varieties, analysed by Minoggio et al. (2003), contain 2.25 to $25.84 \mathrm{mg} / 100 \mathrm{~g}$. Nour et al. (2013) reported concentrations of $30-55.9 \mathrm{mg} / 100 \mathrm{~g}$ in cultivars grown in southwestern Romania. For tomato Portuguese cultivars, Pinela et al. (2012) and Vinha et al. (2014) have obtained phenolic levels of $24.5-31.3 \mathrm{mg} / 100 \mathrm{~g}$ and $22.6-79.3 \mathrm{mg} / 100 \mathrm{~g}$, respectively.

In the present investigation, the highest content of phenolic compounds is obtained in Joker variety. This could be explained by the field grown of this variety compared to other varieties greenhouse grown. Therefore, field grown tomato, which receive higher amount of light have been reported to contain a higher amount of phenolics than greenhouse grown tomatoes (Hunt and Baker, 1980; Davies and Hobson, 1981). Light increases the biosynthesis of phenolic compounds in plants by increasing the activities of enzymes, especially phenylalanine ammonia- 
lyase (PAL). The PAL converts phenylalanine into coumaric acid, which is the precursor of molecules involved in the synthesis of phenolic components (Smith, 1973).

\subsection{DPPH Radical Scavenging Activity}

\subsubsection{DPPH Radical Scavenging Effect of Hexanic Extracts}

To test the scavenging ability of hexanic extracts, the absorbance is measured at $580 \mathrm{~nm}$, using this wavelength, the carotenoid chromophoric system did not produce any interference with DPPH radical (Jiménez-Escrig et al., 2000), and the volume of hexanic extract mixed with methanolic DPPH solution must be lower.

The $\mathrm{DPPH}^{*}$ scavenging activity of the non-polar extracts is illustrated in Fig. 2a. Marmande variety presents the highest activity (29.17\%) followed by Tafna and Zahra which have similar activities.Nattih variety exhibits the weakest antiradical activity (3.42\%). The scavenging power of the hexanic extracts shows linear correlation with total carotenoid and lycopene contents; the correlation coefficients are 0.8 for carotenoids and 0.78 for lycopene.

Jiménez-Escrig et al. (2000) measured the scavenging capacity of several carotenoids by the DPPH method and indicate that lycopene is the carotenoid which presents the best effect. These authors suggest that the antiradical activity increases with the number of double bounds and the presence of the functional groupings as in the xanthophyll class.

\subsubsection{DPPH Radical Scavenging Effect of Alcoholic Extracts}

The scavenging ability of the analysed tomato extracts against the DPPH radical varied depending on the variety and to the extraction solvent (Fig. 2b). The extraction with pure methanol reveals that Joker variety presents the greatest activity with $63.44 \%$. The studied varieties present significant differences ( $<<0.05)$, except Agora and Sammichele. Marmande exhibits the weakest scavenging power (20.18\%).

The extraction with $50 \%$ methanol showed that the antiradical activity ranged between 10.06\% (Sammichele) and 41.27\% (Joker). The scavenging activities of Agora and Zahra do not present a significant difference; Marmande and Sammichele have also almost the same scavenging activity.

The scavenging activity of the ethanolic extract varies from $65.09 \%$ (Joker) to $24.23 \%$ (Marmande); Tafna, Nattih and Zahra samples have similar activities. The extraction with 50\% ethanol shows that Joker and Kiti varieties have the strongest activities with 32.29 and $31.40 \%$, respectively. Tafna, Marmande, Zahra and Sammichele have closer activities ( $\sim 14 \%)$. 
Fig-2. DPPH radical scavenging in hexanic (a) and alcoholic (b) extracts of the tomato varieties
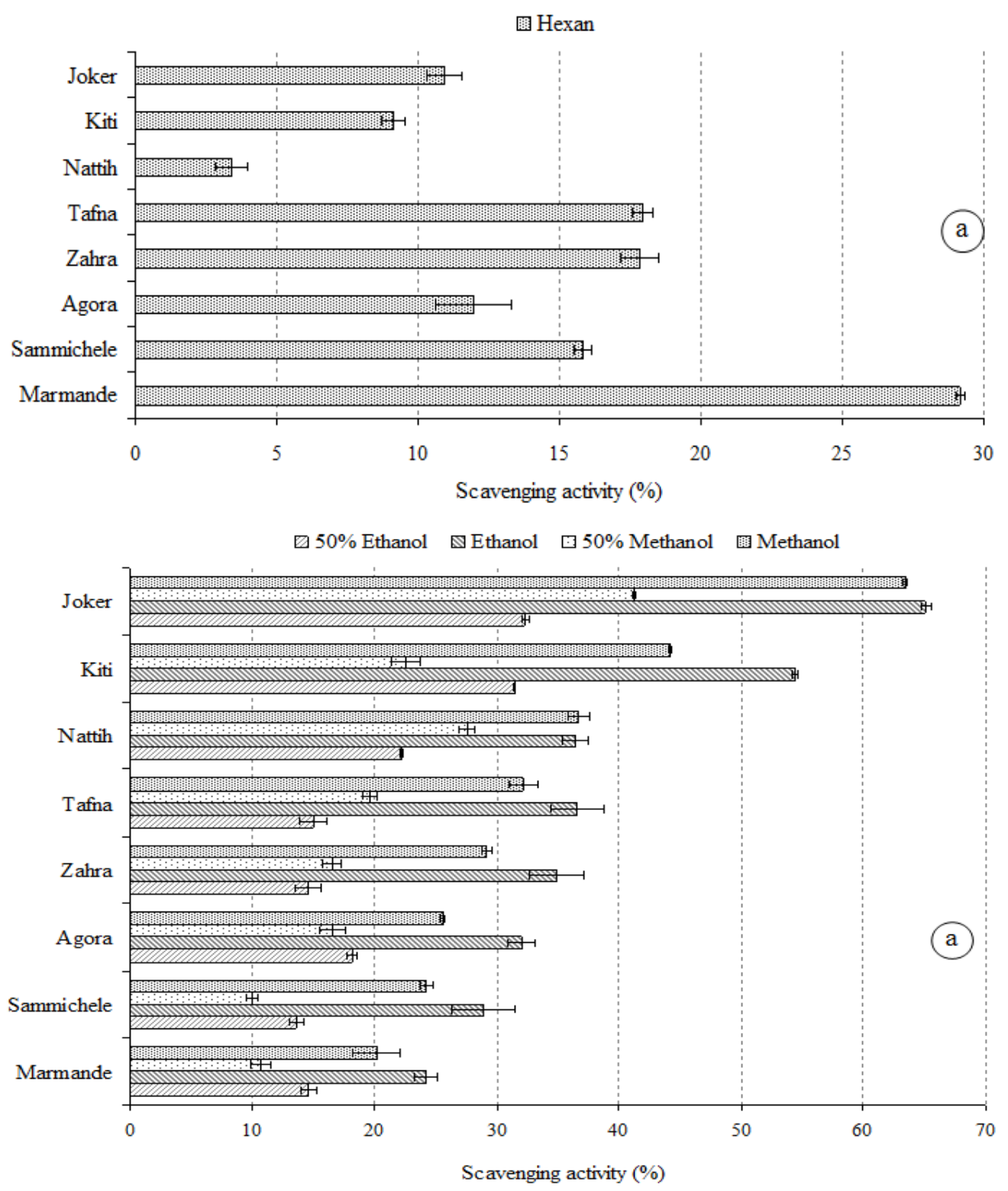

Bars represent the standard error of the mean.

For the four solvents used, Joker variety presents the greatest scavenging activity followed by Kiti, Nattih then Tafna samples, and Marmande has the weakest activity. The extraction with pure alcohol gives a higher scavenging power than that of diluted alcohol. The extraction solvent which gives the best scavenging power is the ethanol. The extracts prepared with $50 \%$ methanol and $50 \%$ ethanol present similar activities.

According to Borguini et al. (2013), DPPH scavenging potential of alcoholic extract of tomatoes cultivated under conventional system (19.52) was higher than that of water extract 
(11.33\%). However, findings of Shahzad et al. (2014) revealed that tomato water extracts scavenge more efficiently DPPH radical (44.63) than methanol extracts (37.68).

The obtained results indicate the existence of a strong linear correlation between the phenolic compound content and the antiradical activity of the extracts (Table 2) and are in agreement with the data of Minoggio et al. (2003).However, Martínez-Valverde et al. (2002) and Hdider et al. (2013) noticed a weak correlation for tomato phenolics extracted with methanol 80\% $(\mathrm{r}=0.42)$ and for high-pigment tomato cultivars grown in Italy $(\mathrm{r}=0.35)$.

\subsection{Reducing Power}

The methanolic extracts present a reducing power ranging between 0.17 (Marmande) and 0.34 (Joker). When $50 \%$ methanol is used as the extraction solvent, the values varied from 0.12 (Marmande) to 0.23 (Joker).The reducing power obtained in the ethanolic extracts ranged between 0.11 and 0.32 while with 50\% ethanol extracts, the values varied from 0.12 to 0.19 (Fig. $3)$.

Fig-3. Reducing power in alcoholic extracts of the tomato varieties

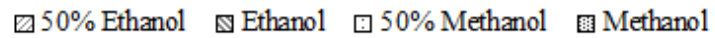

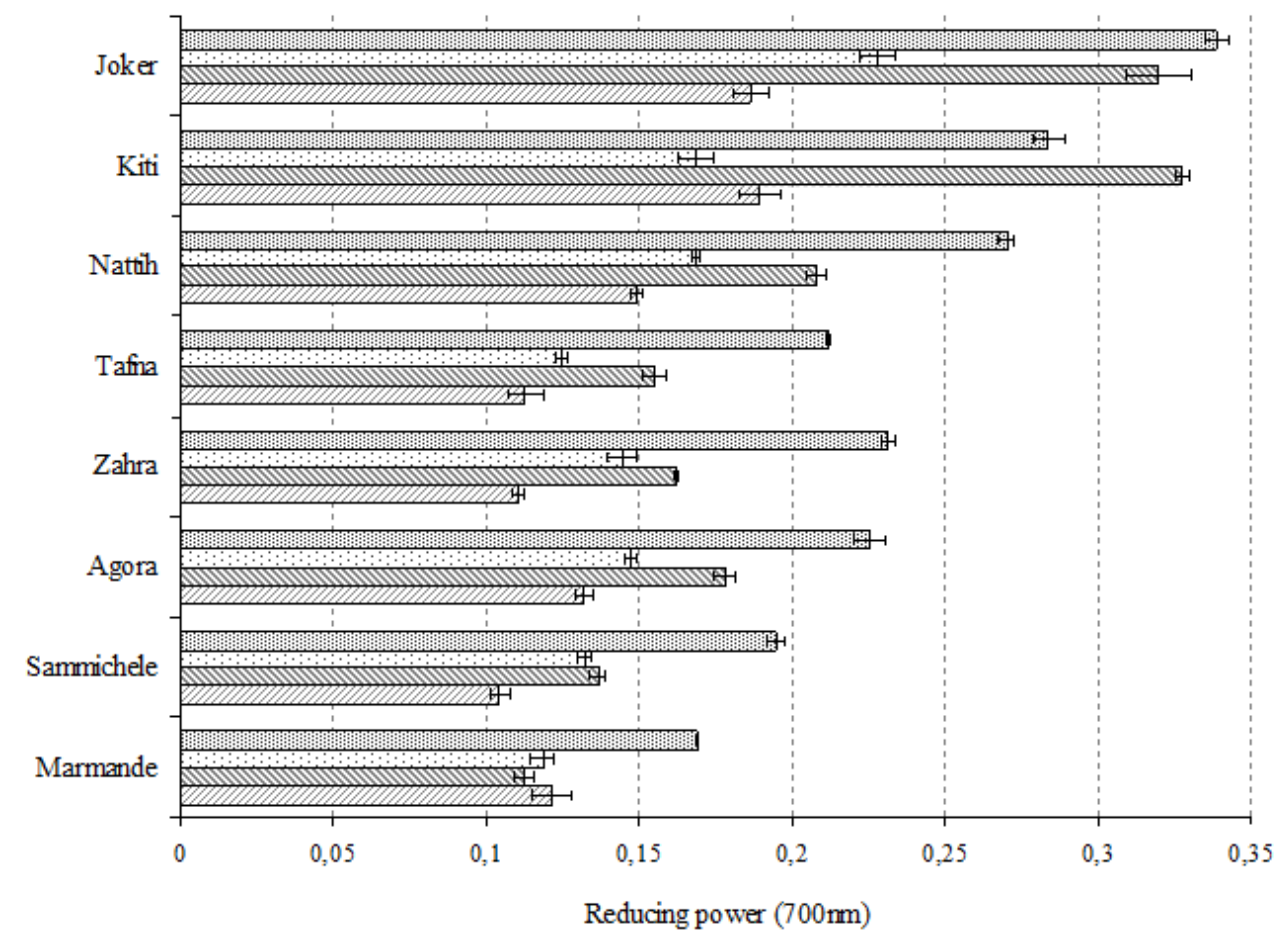

Bars represent the standard error of the mean.

The studied varieties have reducing powers significantly different ( $\mathrm{p}<0.05$ ).Joker presents the greatest value.The best reducing power is obtained with ethanol followed by methanol.The reducing power of $50 \%$ methanol and $50 \%$ ethanol extracts does not present a significant 
difference. The results of reducing power show a good linear correlation with the phenolic compound content of all the extracts (Table 2).

Ascorbic acid extraction is better in an aqueous acid medium. Nevertheless, this vitamin is extracted using alcohol such as methanol (Mau et al., 2005). Ascorbic acid contents measured in the tomato varieties show no obvious relationship (Table 2) with the scavenging activity and reducing power of the alcoholic extracts. This could be explained, on the one hand, by the instability of the ascorbic acid in the alcoholic extracts, on other hand, by the presence of other molecules, such as phenolics, having considerable scavenging and reducing properties, which can mask those of this vitamin.

The scavenging activity and the reducing power, respectively use two mechanisms of action of antioxidants molecules on the free radicals which are the transfers of hydrogen and electron. The scavenging ability on DPPH radical measured in different extracts (methanol, 50\% methanol, ethanol and $50 \%$ ethanol) is correlated with reducing power; the correlation coefficients are 0.95 , $0.93,0.95$ and 0.99 , respectively.

Table-2. Correlation coefficients between phenolic and ascorbic acid contents and antioxidant activity of alcoholic extracts

\begin{tabular}{l|c|c|c|c}
\hline \multirow{2}{*}{ Solvent } & \multicolumn{2}{|c|}{ Antiradical power } & \multicolumn{2}{c}{ Reducing power } \\
\cline { 2 - 5 } & $\begin{array}{c}\text { Phenolic } \\
\text { compounds }\end{array}$ & Ascorbic acid & $\begin{array}{c}\text { Phenolic } \\
\text { compounds }\end{array}$ & Ascorbic acid \\
\hline Methanol & $0.97^{\mathrm{a}}$ & $0.55^{\mathrm{ab}}$ & $0.94^{\mathrm{a}}$ & $0.54^{\mathrm{a}}$ \\
Methanol $50 \%$ & $0.95^{\mathrm{a}}$ & $0.57^{\mathrm{a}}$ & $0.93^{\mathrm{a}}$ & $0.46^{\mathrm{b}}$ \\
Ethanol & $0.96^{\mathrm{a}}$ & $0.48^{\mathrm{bc}}$ & $0.95^{\mathrm{a}}$ & $0.44^{\mathrm{b}}$ \\
Ethanol $50 \%$ & $0.88^{\mathrm{b}}$ & $0.45^{\mathrm{c}}$ & $0.87^{\mathrm{b}}$ & $0.44^{\mathrm{b}}$ \\
\hline
\end{tabular}

Different letters in the same column indicate significant differences ( $\mathrm{p}<0.05)$.

In conclusion, this study indicates that Algerian tomatoes have the same biological properties, are a good source of various antioxidants such as ascorbic acid, phenolic compounds and carotenoids, in particular lycopene, as tomatoes of the other countries. Total phenolic concentrations of the analysed tomatoes differ depending on the variety and the extraction solvent. Pure alcohols (ethanol and methanol) allow better extraction than the diluted ones $(50 \%$ ethanol and 50\% methanol). Positive correlations were found between phenolic, carotenoid and lycopene contents and the antioxidant activities. Using a reduced volume of hexanic extract and measuring the absorbance at $580 \mathrm{~nm}$, the DPPH method could be applied to determining the antioxidant activity of carotenoids. Antioxidant amounts and the antioxidant activity of the tomato varieties show differences which could be due to varietal factors. The hybridisation between Joker and Marmande varieties, which present the highest phenolic and carotenoid amounts respectively, could give another variety with a high antioxidant activity. More work is needed to determine the effects of cooking and storage conditions in the bioactive contents of the studied tomato varieties. 


\section{ACKNOWLEDGMENTS}

The authors are grateful to Miss R. LOUAILECHE and M. ARAB.

\section{REFERENCES}

Abushita, A.A., E.A. Hebshi, H.G. Daood and P.A. Biacs, 1997. Determination of antioxidant vitamins in tomatoes. Food Chemistry, 60(2): 207-212.

Agarwal, S. and A.V. Rao, 2000. Tomato lycopene and its role in human health and chronic diseases. Canadian Medical Association Journal, 163(6): 739-744.

Basuny, A.M., A.M. Gaafar and S.M. Arafat, 2009. Tomato lycopene is a natural antioxidant and can alleviate hypercholesterolemia. African Journal of Biotechnology, 8(23): 6627-6633.

Blum, A., M. Monir, I. Wirsansky and S. Ben-Arzi, 2005. The beneficial effects of tomatoes. European Journal of Internal Medicine, 16(6): 402-404.

Borguini, R.G., D.H. Markowicz Bastos, J.M. Moita-Neto, F.S. Capasso and E.A.F. D. Silva Torres, 2013. Antioxidant potential of tomatoes cultivated in organic and conventional systems. Brazilian Archives of Biology and Technology, 56(4): 521-529.

Brand-Williams, W., M.E. Cuvelier and C. Berset, 1995. Use of a free radical method to evaluate antioxidant activity. LWT - Food Science and Technology, 28(1): 25-30.

Chu, Y.H., C.L. Chang and H.F. Hsu, 2000. Flavonoid content of several vegetables and their antioxidant activity. Journal of the Science of Food and Agriculture, 80(5): 561-566.

Clinton, S.K., 1998. Lycopene: Chemistry, biology and implication for human health and disease. Nutrition Reviews, 56(2): 35-51.

Davies, J.N. and G.E. Hobson, 1981. The constituents of tomato fruit-the influence of environment, nutrition, and genotype. CRC Critical Reviews in Food Science and Nutrition, 15(3): 205-280.

Dumas, Y., M. Dadomo, G. Di Lucca and P. Grolier, 2003. Effects of environmental factors and agricultural techniques on antioxidant content of tomatoes. Journal of the Science of Food and Agriculture, 83(5): 369-382.

FAO, 2012. Available from http://faostat.fao.org/site/567/default.aspx [Accessed 15 may 2014].

Frusciante, L., P. Carli, M.R. Ercolano, R.D.M. Pernice, A., V. Fogliano and N. Pellegrini, 2007. Antioxidant nutritional quality of tomato. Molecular Nutrition and Food Research, 51(5): 609-617.

George, B., C. Kaur, D.S. Khurdiya and H.C. Kapoor, 2004. Antioxidants in tomato (Lycopersium Esculentum) as a function of genotype. Food Chemistry, 84(1): 45-51.

Grosso, G., S. Buscemi, F. Galvano, A. Mistretta, S. Marventano, V. La Vela, D. Filippo, S. Gangi, F. Basile and A. Biondi, 2013. Mediterranean diet and cancer: Epidemiological evidence and mechanism of selected aspects. MBC Surgery, 13(Suppl 2): 1471-2482.

Hallmann, E., 2012. The influence of organic and conventional cultivation systems on the nutritional value and content of bioactive compounds in selected tomato types. Journal of the Science of Food and Agriculture, 92(14): 2840-2848.

Harasym, J. and R. Oledzki, 2014. Effect of fruit and vegetable antioxidants on total antioxidant capacity of blood plasma. Nutrition, $30(5): 511-517$. 
Hart, D.J. and K.J. Scott, 1995. Development and evaluation of an HPLC method for the analysis of carotenoids in foods, and the measurement of the carotenoid content of vegetables and fruits commonly consumed in the UK. Food Chemistry, 54(1): 101-111.

Hdider, C., R. Ilahy, I. Tlili, M.S. Lenucci and G. Dalessandro, 2013. Effect of the stage of maturity on the antioxidant content and antioxidant activity of high-pigment tomato cultivars grown in Italy. Food, 7(1): 1-7.

Hunt, G.M. and E.A. Baker, 1980. Phenolic constituents of tomato fruit cuticles. Phytochemistry, 19(7): 1415-1419.

Jiménez-Escrig, A., I. Jiménez-Jiménez, C. Sánchez-Moreno and F. Saura-Calixto, 2000. Evaluation of free radical scavenging of dietary carotenoids by the stable radical 2,2-diphenyl-1-picrylhydrazyl. Journal of the Science of Food and Agriculture, 80(11): 1686-1690.

Kaur, C. and H.C. Kapoor, 2002. Anti-oxidant activity and total phenolic content of some Asian vegetables. International Journal of Food Science and Technology, 37(2): 153-161.

Klein, B.P. and A.K. Perry, 1982. Ascorbic acid and vitamin a activity in selected vegetables from different geographical areas of the United States. Journal of Food Science, 47(3): 941-948.

Kuti, J.O. and H.B. Konuru, 2005. Effects of genotype and cultivation environment on lycopene content in red-ripe tomatoes. Journal of the Science of Food and Agriculture, 85(12): 2021-2026.

Livny, O., I. Kaplan, R. Reifen, S. Polak-Charcon, Z. Madar and B. Schwartz, 2002. Lycopene inhibits proliferation and enhances gap-junctional communication of KB-1 human oral tumor cells. Journal of Nutrition, 132(12): 3754-3759.

Martínez-Valverde, I., M.J. Periago, G. Provan and A. Chesson, 2002. Phenolic compounds, lycopene and antioxidant activity in commercial varieties of tomato (Lycopersicum Esculentum). Journal of the Science of Food and Agriculture, 82(2): 323-330.

Mau, J.L., S.Y. Tsai, Y.H. Tseng and S.J. Huang, 2005. Antioxidant properties of methanolic extracts from ganoderma tsugae. Food Chemistry, 93(4): 641-649.

Minoggio, M., L. Bramati, P. Simonetti, C. Gardana, L.S. Iemoli, E., P.L. Mauri, P. Spigno, G.P. Soressi and P.G. Pietta, 2003. Polyphenol pattern and antioxidant activity of different tomato lines and cultivars. Annals of Nutrition and Metabolism, 47(2): 64-69.

Nour, V., M.E.I. Trandafir and Ionica, 2013. Antioxidant compounds, mineral content and antioxidant activity of several tomato cultivars grown in Southwestern Romania. Notulae Botanicae Horti Agrobotanici, 41(1): 136-142.

Odabasoglu, F., A. Aslan, A. Cakir, H. Suleyman, Y. Karagoz, M. Halici and Y. Bayir, 2004. Comparison of antioxidant activity and phenolic content of three lichen species. Phytotherapy Research, 18(11): 938-941.

Pinela, J., L. Barros, A.M. Carvalho and I.C.F.R. Ferreira, 2012. Nutritional composition and antioxidant activity of four tomato (Lycopersicon Esculentum L.) farmer' varieties in North Eastern Portugal. homegardens. Food and Chemical Toxicology, 50(3-4): 829-834.

Ribéreau-Gayon, P., 1968. Propriétés chimiques des phénols. Applications aux produits naturels. In: Les composés phénoliques des végétaux. Dunod, Paris, France. pp: 28-57. 
Sadler, G., J. Davis and D. Dezman, 1990. Rapid extraction of lycopene and b-carotene from reconstituted tomato paste and pink grapefruit homogenates. Journal of Food Science, 55(5): 1460-1461.

Shahzad, T., I. Ahmad, S. Choudhry, M.K. Saeed and M.N. Khan, 2014. DPPH free radical scavenging activity of tomato, cherry tomato and watermelon: Lycopene extraction, purification and quantification. International Journal of Pharmacy and Pharmaceutical Sciences, 6(2): 223-228.

Shi, J. and M. Le Maguer, 2000. Lycopene in tomatoes. Chemical and physical properties affected by food processing. Critical Reviews Food Science and Nutrition, 4O(1): 1-42.

Shi, J., J. Yu, J. Pohorly, J.C. Young, M. Bryan and Y. Wu, 2003. Optimization of the extraction of polyphenols from grape seed meal by aqueous ethanol solution. Journal of Food Agriculture and Environment, 1(2): 42-47.

Singleton, V.L. and J.A. Rossi, 1965. Colorimetry of total phenolics with phosphomolybdic-phosphotungstic acid reagents. American Journal of Enology and Viticulture, 16(3): 144-158.

Smith, H., 1973. Regulatory mechanisms in the photocontrol of flavonoid biosynthesis. In: B.V. Milborrow, Biosynthesis and its control in plants. New York: Academic Press. pp: 303-320.

Toor, R.K., G.P. Savage and C.E. Lister, 2006. Seasonal variations in the antioxidant composition of greenhouse grown tomatoes. Journal of Food Composition and Analysis, 19(1): 1-10.

Vinha, A.F., R.C. Alves, S.V.P. Barreira, A. Castro, A.S.G. Costa and M.B.P.P. Oliveira, 2014. Effect of peel and seed removal on the nutritional value and antioxidant activity of tomato (Lycopersicon Esculentum L.) fruits. LWT - Food Science and Technology, 55(1): 197-202.

Weisburger, J.H., 2002. Lycopene and tomato products in health promotion. Experimental Biology and Medicine, 227(10): 924-927.

Willis, M.S. and F.H. Wians, 2003. The role of nutrition in preventing prostate cancer: A review of the proposed mechanisms of action of various dietary substances. Clinica Chimica Acta, 330: 57-83.

Woodall, A.A., S.W. Lee, R.J. Weesie, M. Jackson and G. Britton, 1997. Oxidation of carotenoids by free radicals: Relationship between structure and reactivity. Biochimica \& Biophysica Acta, 1336(1): 3342.

Wootton-Beard, P.C. and L. Ryan, 2011. Improving public health? The role of antioxidant-rich fruit and vegetable beverages. Food Research International, 44(10): 3135-3148.

Yen, G.C. and H.Y. Chen, 1995. Antioxidant activity of various tea extracts in relation to their antimutagenicity. Journal of Agricultural and Food Chemistry, 43(1): 27-32.

Zoran, I.S., K. Nikolaos and S. Ljubomir, 2014. Tomato fruit quality from organic and conventional production. In: V. Pilipavicius, Organic agriculture towards sustainability. Rijeka, Croatia: In Tech Europe. pp: 147-169.

Views and opinions expressed in this article are the views and opinions of the author(s), Journal of Food Technology Research shall not be responsible or answerable for any loss, damage or liability etc. caused in relation to/arising out of the use of the content. 